\title{
Trends in young adult mortality in three European cities: Barcelona, Bologna and Munich, 1986-1995
}

\author{
C Borrell, M I Pasarín, E Cirera, P Klutke, E Pipitone, A Plasència
}

\begin{abstract}
Objective-In recent decades, in most European countries young adult mortality has risen, or at best has remained stable. The aim of this study was to describe trends in mortality attributable to the principal causes of death: AIDS, drug overdose, suicide and motor vehicle traffic accidents, among adults aged between 15 and 34 years in three European cities (Barcelona, Bologna and Munich), over the period 1986 to 1995 .
\end{abstract}

Methods-The population studied consisted of all deaths that occurred between 1986 and 1995 among residents of Barcelona, Bologna and Munich aged from 15 to 34 years. Information about deaths was obtained from mortality registers. The study variables were sex, age, the underlying cause of death and year of death. Causes of death studied were: drug overdose, AIDS, suicide and motor vehicle traffic accidents. Age standardised mortality rates (direct adjustment) were obtained in all three cities for the age range 15-34. To investigate trends in mortality over the study period Poisson regression models were fitted, obtaining the average relative risk (RR) associated with a one year increment.

Institut Municipal de Salut Pública, Ajuntament de Barcelona, Spain

C Borrell

M I Pasarín

E Cirera

A Plasència

Institut für

Medizinsche

Informatik und

Systemforschung,

Neuherberg, Germany

P Klutke

Osservatorio

Epidemiologico,

Bologna, Italy

E Pipitone

Universitat Autònoma de Barcelona, Spain A Plasència

Correspondence to: Dr Borrell, Municipal Institute of Public Health, Plaça Lesseps 1, 08023 Barcelona, Spain

(cborrell@imsb.bcn.es)

Accepted for publication 26 March 2001 Results-Young adult mortality increased among men in Barcelona and Bologna (RR per year: $1.04,95 \%$ confidence intervals $(95 \% \mathrm{CI}): 1.03,1.06$ in Barcelona and RR:1.03, 95\%CI:1.01, 1.06 in Bologna) and among women in Barcelona (RR:1.02, 95\%CI: 1.01, 1.04), with a change in the pattern of the main causes of death attributable to the increase in AIDS and drug overdose mortality. In Munich, the pattern did not change as much, suicides being the main cause of death during the 10 years studied, although they have been decreasing since 1988 (RR:0.92, 95\%CI:0.88, 0.96 for men and $0.81,95 \% \mathrm{CI}$ : 0.75-0.87 for women).

Conclusion-The increase in AIDS mortality observed in the three European cities in the mid-80s and mid-90s has yielded to substantial changes in the pattern of the main causes of death at young ages in Barcelona and Bologna. Munich presented a more stable pattern, with suicide as the main cause of death.

(F Epidemiol Community Health 2001;55:577-582)
In recent decades, adult mortality rates have declined in the majority of European Union countries, mainly because of the reduction in deaths from cardiovascular and cerebrovascular diseases. ${ }^{1}$ However, this generalised decline is not homogeneous in all age groups, as among young adults the death rates have risen, or at best have remained stable..$^{2-7}$

The main causes of death among young adults in most European countries are AIDS, drug overdose, suicide and traffic accidents, all causes related with life styles and risk behaviours, and therefore avoidable. ${ }^{2468}$ The only differential feature from one country to another is the magnitude of the rates and the order in which they appear in the ranking of the main causes.

Thus, since the appearance of AIDS, mortality attributable to this cause has increased more rapidly in the countries of southern Europe $^{39-11}$ and is currently higher than in the northern and central European countries. ${ }^{12}$ This higher rate is mainly explained by the higher percentage of injecting drug users. In some countries this transmission group accounts for over $60 \%$ of AIDS cases diagnosed. ${ }^{3589}$ Conversely, in the case of suicide, the northern and central European countries show higher rates. ${ }^{13-15}$ These differences could be explained, once again, by social factors (religion, unemployment, divorce) and psychological factors (mental or physical illness, alcoholism). ${ }^{16}$

Some causes of death tend to concentrate in urban areas, such as AIDS and drug abuse, ${ }^{4-19}$ and therefore it is important to analyse mortality trends in cities of different locations within Europe. Thus, the aim of this study was to describe trends in mortality attributable to the principal causes of death, AIDS, drug overdose, suicide and motor vehicle traffic accidents, among adults aged between 15 and 34 years in three European cities (Barcelona, Bologna and Munich), over the period from 1986 to 1995.

\section{Methods}

THE CITIES STUDIED

Barcelona is the second largest city in Spain and it is located in the north east of the country. Its population has decreased from 1701812 inhabitants in 1986 to 1508805 in 1996, with an increasingly aging population, resulting from higher life expectancy and decreasing fertility rates. The majority of its population works in the service sector. Unemployment rates in the province of Barcelona have been relatively high, fluctuating between $14 \%$ and $25 \%$. 
Table 1 Death cases and standardised mortality rates, by year, in the 15-34 years age group, in Barcelona, Bologna and Munich by sex, 1986-1995

\begin{tabular}{|c|c|c|c|c|c|c|c|c|c|}
\hline \multirow[b]{2}{*}{ Year } & \multicolumn{3}{|c|}{ Barcelona } & \multicolumn{3}{|c|}{ Bologna } & \multicolumn{3}{|c|}{ Munich } \\
\hline & $\begin{array}{l}\text { Death } \\
\text { cases }\end{array}$ & $\%^{*}$ & $\begin{array}{l}\text { Standardised } \\
\text { mortality } \\
\text { rate } \times 10^{6}\end{array}$ & $\begin{array}{l}\text { Death } \\
\text { cases }\end{array}$ & $\%$ * & $\begin{array}{l}\text { Standardised } \\
\text { mortality } \\
\text { rate } \times 10^{6}\end{array}$ & $\begin{array}{l}\text { Death } \\
\text { cases }\end{array}$ & $\%^{*}$ & $\begin{array}{l}\text { Standardised } \\
\text { mortality } \\
\text { rate } \times 10^{6}\end{array}$ \\
\hline \multicolumn{10}{|l|}{ Men } \\
\hline 1986 & 245 & 3.2 & 99.1 & 52 & 1.9 & 87.4 & 163 & 2.7 & 76.6 \\
\hline 1987 & 259 & 3.3 & 104.7 & 78 & 2.9 & 133.6 & 185 & 3.2 & 84.4 \\
\hline 1988 & 381 & 5.0 & 154.4 & 74 & 2.7 & 127.3 & 207 & 3.6 & 97.9 \\
\hline 1989 & 405 & 5.0 & 164.3 & 82 & 3.2 & 141.0 & 187 & 3.2 & 86.2 \\
\hline 1990 & 413 & 4.7 & 168.0 & 94 & 3.4 & 164.5 & 181 & 3.0 & 84.2 \\
\hline 1991 & 413 & 4.8 & 167.9 & 95 & 3.4 & 163.0 & 230 & 3.8 & 103.8 \\
\hline 1992 & 458 & 5.4 & 185.9 & 99 & 3.8 & 170.9 & 212 & 3.7 & 92.3 \\
\hline 1993 & 435 & 5.2 & 176.1 & 84 & 2.8 & 146.1 & 227 & 3.9 & 95.1 \\
\hline 1994 & 410 & 5.0 & 167.2 & 76 & 2.7 & 145.7 & 201 & 3.4 & 82.4 \\
\hline 1995 & 404 & 4.8 & 166.0 & 78 & 2.9 & 152.1 & 210 & 3.6 & 86.4 \\
\hline \multicolumn{10}{|c|}{ Women } \\
\hline 1986 & 119 & 1.5 & 49.1 & 29 & 1.0 & 53.6 & 102 & 1.5 & 48.0 \\
\hline 1987 & 123 & 1.5 & 49.9 & 36 & 1.3 & 66.1 & 69 & 1.0 & 32.3 \\
\hline 1988 & 132 & 1.8 & 54.0 & 39 & 1.4 & 71.1 & 80 & 1.2 & 38.3 \\
\hline 1989 & 143 & 1.8 & 59.0 & 27 & 1.0 & 49.4 & 79 & 1.1 & 37.6 \\
\hline 1990 & 152 & 1.8 & 62.4 & 22 & 0.7 & 40.9 & 98 & 1.4 & 45.0 \\
\hline 1991 & 178 & 2.0 & 72.6 & 43 & 1.5 & 79.7 & 86 & 1.2 & 42.6 \\
\hline 1992 & 158 & 2.0 & 64.6 & 32 & 1.1 & 59.2 & 108 & 1.6 & 49.7 \\
\hline 1993 & 147 & 1.8 & 60.1 & 28 & 1.0 & 50.7 & 76 & 1.1 & 34.8 \\
\hline 1994 & 133 & 1.6 & 54.5 & 26 & 0.9 & 47.2 & 74 & 1.1 & 33.6 \\
\hline 1995 & 162 & 2.0 & 66.1 & 29 & 1.0 & 60.0 & 75 & 1.1 & 34.9 \\
\hline
\end{tabular}

*Percentage of the 15-34 age group mortality over all deaths in each year.

Bologna is situated in the north of Italy, with a population of 437203 inhabitants in 1985 and 386491 in 1995. It also has the majority of its population working in the service sector. Unemployment was lower than in Barcelona (3.4\% in 1985 and $6.1 \%$ in 1995 ).

Munich is the third largest city in Germany, and it is located in the south east of the country. It is the capital of Bavaria. The population was 1281645 inhabitants in 1986 and 1323624 in 1995 (20\% being foreigners). The area of Munich has the second highest number of working people in Germany and is the leading centre for high tech and media industries. Unemployment rates in Munich have been fluctuating between $3.9 \%$ and $7 \%$.

SOURCES OF INFORMATION

The population studied consisted of all deaths that occurred between 1986 and 1995 among residents of Barcelona, Bologna and Munich aged from 15 to 34 years. Information about deaths was obtained from death certificates; mortality registers were local in Barcelona and Bologna and were maintained by the municipal administration. In Munich this information was obtained from the regional register of mortality. Population data were obtained from municipal censuses of the three cities: in Barcelona municipal censuses were available for 1981, 1986 and 1991 and intercensal populations were obtained for the other years through the method based in the geometric curve, ${ }^{20}$ in Bologna and Munich the municipal census is updated every year.

VARIABLES

The study variables were sex, age, underlying cause of death and year of death. The underlying cause of death was coded using the International Classification of Diseases, 9th revision (ICD-9). ${ }^{21}$ Causes of death studied were the main causes of death in the 15-34 years age group of Barcelona: drug overdose (ICD-9 codes: Barcelona E850-E858 as accidental drug poisoning; Bologna 304.0 and 304.9, and Munich 304 as drug dependence), AIDS (ICD-9 codes: Barcelona 279.5, Bologna 279.1 and Munich 042-044), suicide (ICD-9 codes: E950-E959 in all three cities) and motor vehicle traffic accidents (ICD-9 codes: E810-E829 in all three cities). Barcelona uses different coding for drug use because of forensic traditions, ${ }^{22}$ and AIDS codes were different because, as a new disease, different ICD-9 codes were used in each country.

\section{DATA ANALYSIS}

Age standardised mortality rates (direct adjustment) in all three cities for the age range 15-34 were computed. The Standard European population proposed by the World Health Organisation $^{23}$ was used as the reference population for adjustment, as well as the three cities' population censuses as the rate denominators.

To investigate trends in mortality over the study period Poisson regression models were fitted, obtaining the average relative risks (RR) associated with a one year increment. Separate models for each sex were built. Mortality was the dependent variable, and age group (15-19, 20-24, 25-29 and 30-34 years) and year of death the independent ones. As motor vehicle traffic accident mortality in Barcelona and suicide mortality in Munich showed a sharp change in 1988, the Poisson regression models were fitted using data from that year onwards.

\section{Results}

The percentage of deaths in the 15-34 age group over all deaths was higher in men than in women, being over 3\% in men in Barcelona

Table 2 Percentage of deaths by cause in the 15-34 years age group and number of death cases ( $n$ ) in Barcelona, Bologna and Munich by sex, 1986 and 1995

\begin{tabular}{|c|c|c|c|c|c|c|}
\hline & \multicolumn{2}{|l|}{ Barcelona } & \multicolumn{2}{|l|}{ Bologna } & \multicolumn{2}{|l|}{ Munich } \\
\hline & $\begin{array}{l}1986 \\
\%(n)\end{array}$ & $\begin{array}{l}1995 \\
\%(n)\end{array}$ & $\begin{array}{l}1986 \\
\%(n)\end{array}$ & $\begin{array}{l}1995 \\
\%(n)\end{array}$ & $\begin{array}{l}1986 \\
\%(n)\end{array}$ & $\begin{array}{l}1995 \\
\%(n)\end{array}$ \\
\hline \multicolumn{7}{|l|}{ Men } \\
\hline AIDS & $1.2(3)$ & $41.3(167)$ & $7.7(4)$ & $38.5(30)$ & $0.0(0)$ & $15.7(33)$ \\
\hline Drug overdose & $8.2(20)$ & $16.8(68)$ & $1.9(1)$ & $6.4(5)$ & $0.6(1)$ & $14.8(31)$ \\
\hline Motor vehicle & $20.8(51)$ & $6.7(27)$ & $30.8(16)$ & $19.2(15)$ & $25.2(41)$ & $11.4(24)$ \\
\hline Suicide & $10.6(26)$ & $7.9(32)$ & $17.3(9)$ & $10.3(8)$ & $31.3(51)$ & $18.1(38)$ \\
\hline All causes & $100.0(245)$ & $100.0(404)$ & $100.0(52)$ & $100.0(78)$ & $100.0(163)$ & $100.0(210)$ \\
\hline \multicolumn{7}{|l|}{ Women } \\
\hline AIDS & $1.7(2)$ & $30.9(50)$ & $3.4(1)$ & $41.4(12)$ & $0.0(0)$ & $9.3(7)$ \\
\hline Drug overdose & $0.8(1)$ & $12.3(20)$ & $0.0(0)$ & $0.0(0)$ & $2.0(2)$ & $16.0(12)$ \\
\hline Motor vehicle & $21.8(26)$ & $8.0(13)$ & $17.2(5)$ & $17.2(5)$ & $9.8(10)$ & $1.3(1)$ \\
\hline Suicide & $9.2(11)$ & $3.1(5)$ & $13.8(4)$ & $6.9(2)$ & $25.5(26)$ & $20.0(15)$ \\
\hline All causes & $100.0(119)$ & $100.0(162)$ & $100.0(29)$ & $100.0(29)$ & $100.0(102)$ & $100.0(75)$ \\
\hline
\end{tabular}


Table 3 Risk relative (RR) of mortality (15-34 age group) of a one year change and 95\% confidence intervals (95\% CI) obtained by Poisson regression models by sex and cause of death in Barcelona, Bologna and Munich, 1986-1995

\begin{tabular}{|c|c|c|c|c|c|c|}
\hline & \multicolumn{2}{|c|}{ Barcelona } & \multicolumn{2}{|c|}{ Bologna } & \multicolumn{2}{|c|}{ Munich } \\
\hline & $R R$ & $95 \% C I$ & $R R$ & $95 \% C I$ & $R R$ & $95 \% C I$ \\
\hline \multicolumn{7}{|l|}{ Men } \\
\hline AIDS & 1.26 & $1.24,1.29$ & 1.15 & $1.09,1.20$ & 1.24 & $1.17,1.32$ \\
\hline Drug overdose & 1.08 & $1.05,1.11$ & 1.00 & $0.93,1.08$ & 1.25 & $1.19,1.32$ \\
\hline Motor vehicle & 0.89 & $0.85,0.92$ & 1.00 & $0.96,1.06$ & 0.93 & $0.89,0.97$ \\
\hline Suicide ${ }^{\star}$ & 1.03 & $0.98,1.07$ & 1.00 & $0.93,1.07$ & 0.92 & $0.88,0.96$ \\
\hline All causes & 1.04 & $1.03,1.06$ & 1.03 & $1.01,1.06$ & 1.01 & $0.99,1.02$ \\
\hline \multicolumn{7}{|l|}{ Women } \\
\hline AIDS & 1.28 & $1.22,1.35$ & 1.16 & $1.07,1.26$ & 1.27 & $1.11,1.46$ \\
\hline Drug overdose & 1.06 & $1.00,1.11$ & 1.06 & $0.88,1.27$ & 1.21 & $1.10,1.34$ \\
\hline Motor vehicle ${ }^{\star}$ & 0.87 & $0.81,0.94$ & 0.98 & $0.88,1.09$ & 0.89 & $0.83,0.95$ \\
\hline Suicide ${ }^{\star}$ & 0.97 & $0.90,1.04$ & 0.88 & $0.77,1.02$ & 0.81 & $0.75,0.87$ \\
\hline All causes & 1.02 & $1.01,1.04$ & 0.99 & $0.95,1.03$ & 0.98 & $0.96,1.00$ \\
\hline
\end{tabular}

${ }^{\star}$ By motor vehicle traffic accidents in Barcelona and suicides in Munich we analysed data since 1988. cities, but mainly in Barcelona and Bologna, representing in 1995 more than $30 \%$ of deaths in this age group. The percentage attributable to drug overdose has increased in Barcelona and Munich, being around $15 \%$ in 1995 . Consequently, the percentages of deaths attributable to motor vehicle traffic accidents and suicide have decreased in the three cities.

Standardised death rates in the 15-34 year age group for the years 1986 to 1995 for the three cities are presented in table 1. Barcelona and Bologna showed similar rates, both higher than in Munich, and higher in men than in women. In the study period, total mortality increased in Barcelona in men (RR per year: $1.04,95 \%$ confidence intervals $(95 \% \mathrm{CI}): 1.03$, 1.06) and women (RR:1.02, 95\%CI: 1.01, 1.04), and in Bologna in men (RR:1.03, 95\% CI: 1.01, 1.06) (table 3).

Figure 1 depicts the trends in cause specific mortality in each city. It may be observed that the pattern changed during the study period in Barcelona and in Bologna. The main cause of death in 1986 was motor vehicle traffic accidents while in 1995 it was AIDS, with a large increase in the latter cause of death attributable to AIDS has increased in the three

\section{- AIDS}

- Motor vehicle accident

- Drug overdose Suicide
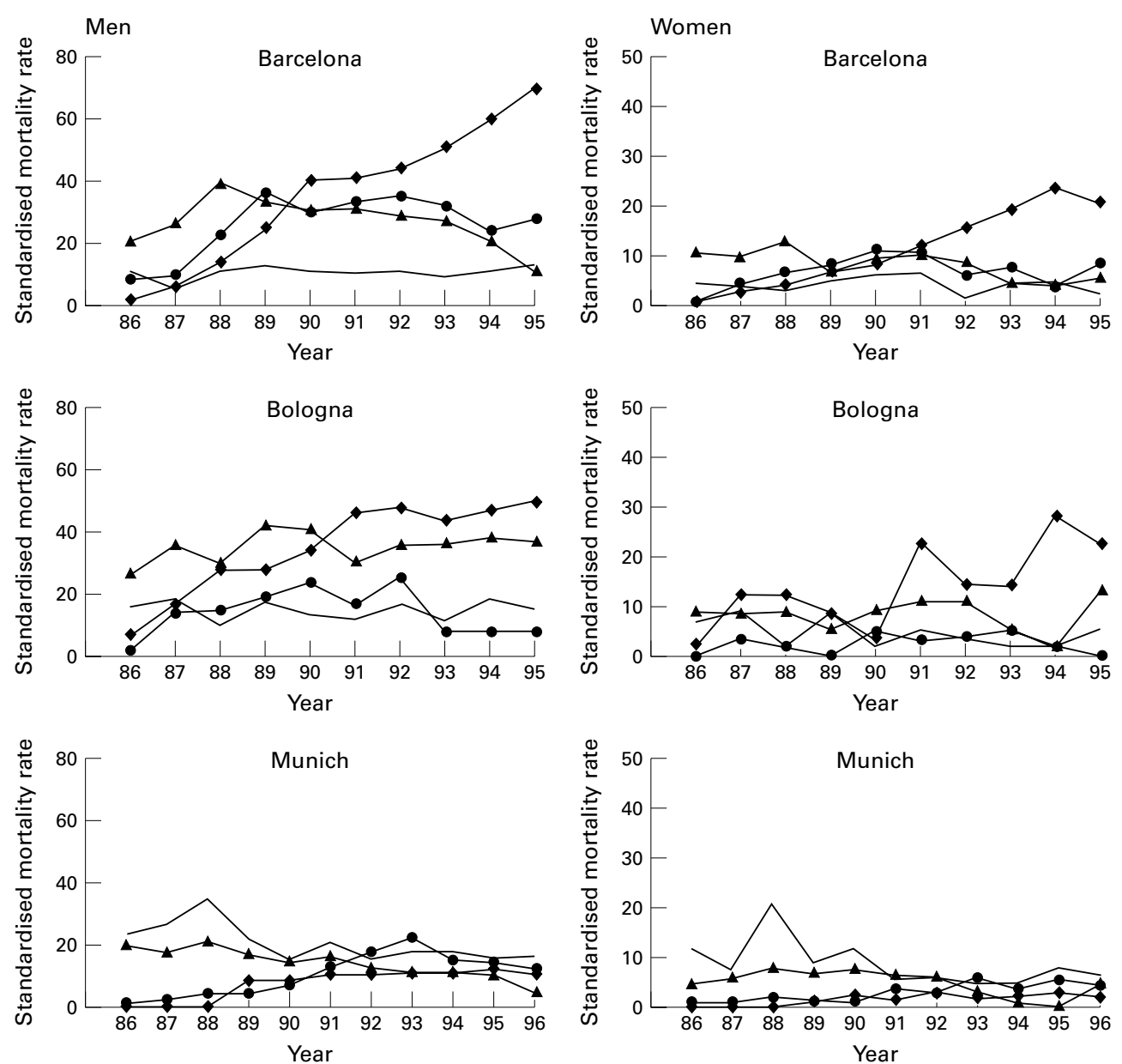

Figure 1 Trends in standardised mortality rates in young adults aged from 15 to 34 in Barcelona, Bologna and Munich by sex, 1986-1995. 
KEY POINTS

- The main causes of death among young adults in most European countries are AIDS, drug overdose, suicide and traffic accidents, all causes related with life styles and risk behaviours, and therefore avoidable.

- The aim of this study was to describe trends in mortality among adults aged between 15 and 34 years in three European cities (Barcelona, Bologna and Munich), over the period 1986 to 1995 .

- The study has shown the increase in young adult mortality among men and women in Barcelona and among men in Bologna, the pattern of the main causes of death changing because of the increase in AIDS and drug overdose mortality. In Munich, the pattern did not change as much, suicides being the main cause of death during the 10 years studied.

- Greater efforts should be devoted at the European level to monitor trends in health outcomes and determinants in major cities, favouring more systematic and harmonised procedures to analyse and disseminate comparable results.

during these years, mainly in men (RR:1.26, 95\% CI: $1.24,1.29$ in Barcelona and RR:1.15, 95\% CI: 1.09, 1.20 in Bologna) (table 3). Drug overdose also increased in Barcelona. From 1988 onwards, motor vehicle traffic accident deaths decreased in Barcelona $(\mathrm{RR}=0.89$, 95\% CI: $0.85,0.92$ for men and $\mathrm{RR}=0.87$, 95\% CI: $0.81,0.94$ for women). In Munich the pattern did not change as much, suicides being the main cause of death during the 10 years studied, although they have been decreasing since 1988 (RR:0.92, 95\%CI:0.88, 0.96 for men and 0.81, 95\% CI: 0.75, 0.87 for women). Deaths attributable to AIDS and drug overdose also increased in Munich, although AIDS has never been the main cause of death whereas motor vehicle traffic accident deaths decreased during the period (fig 1 and table 3 ).

\section{Discussion}

This is the first study looking at trends in mortality among three large European cities, each one reflecting the differential impact of the main causes of death in the young adult population. The study has shown the increase in young adult mortality among men and women in Barcelona and among men in Bologna, the pattern of the main causes of death changing because of the increase in AIDS and drug overdose mortality.

By the end of the study period, AIDS had became the leading cause of death in adults aged from 15-34 years in Barcelona and Bologna, and had also increased in Munich. These trends are related with AIDS incidence; Spain and Italy, as other southern European countries, have the highest rates in the European Union. ${ }^{17}$ In Italy and Spain, AIDS and drug use are related because $60 \%$ of the AIDS cases are drug users who are at risk of contracting the disease through both needle sharing and sexual contacts. ${ }^{13} 24$ The majority of AIDS deaths are men who are also drug users. This pattern is very different from that of northern and central European countries, where AIDS incidence rates are lower and the majority of cases are men of homo/bisexual transmission group. ${ }^{12} 25$ These differences may explain the results found in Barcelona and Bologna compared with those of Munich. Other studies have reported similar results, although most are based on countries rather than cities. ${ }^{2-4}$ 6-8 111726

Drug overdose was the second most important cause of death in Barcelona at the end of the period, and it also increased in Munich. Compared with other European cities, Barcelona has a high prevalence of heroin users, ${ }^{27}$ which may explain the trends observed. It should be noted that mortality among drug users in southern European countries is mainly attributable to AIDS followed by drug overdose, ${ }^{928-30}$ while in northern and central European countries the two leading causes are drug overdose and suicide. ${ }^{31} 32$

In Munich, the principal cause of death for most of the study period was suicide although it has been decreasing since 1988, a trend similar to that described for Germany as a whole. ${ }^{33}$ The rates are clearly higher than those observed for Barcelona and Bologna, which remained stable over the study period. Again, for this cause, differences may be appreciated between northern-central and southern European countries, differences similar to those already reported in the literature, ${ }^{13151634}$ and that are related to economic and social factors such as unemployment and religion. ${ }^{16}{ }^{35-37}$ Although several studies have found a relation among unemployment and suicide at an individual level, ${ }^{38-40}$ the findings at an aggregate level are more controversial. ${ }^{157}$ As it has been pointed out, the level of unemployment was higher in Barcelona than in Bologna and Munich. Also, a relation between the degree of "religiousness" and suicide rates has been described. ${ }^{16}{ }^{36}$ In a recent analysis of ecological data of 26 countries, Spain and Italy were countries with more prevalence of religiosity (measured by an index) than Germany, and both with lower suicide rates. ${ }^{41}$

The rate of deaths attributable to motor vehicle traffic accidents was higher in Barcelona and Bologna and in men, decreasing in Barcelona from 1988 onwards. It has been reported that southern European countries have had consistently higher traffic related mortality than northern and central European countries, ${ }^{42}$ a situation largely related with a stronger increase in motorisation in the former countries, ${ }^{43}$ together with higher mean speeds and a lower use of protective devices, ${ }^{44}$ although road conditions and health care infrastructures could also account for some of the observed differences.

It should be noted that one of the limitations of this study may be the underreporting of the causes of death studied, ${ }^{27}$ 45-48 which may underestimate the cause specific mortality. Nevertheless, total mortality in the age group studied and trends in the same city are not 
affected by this underreporting. In a study on improvement of the quality and comparability of causes of death statistics inside the European Union, suicide, accidental deaths and drug related deaths were focused as causes of death requiring special attention. ${ }^{49}$

Moreover, although slightly different coding criteria for causes of death were used in each city, there is no evidence that for the case of AIDS and drug overdose deaths this may have had a substantial influence in data comparability. Although we are aware this study has included mortality data until 1995, a period after which AIDS incidence rates have tended to decrease in most Western European countries, the period covered is valid to document the major changes in mortality profiles having occurred in certain European areas in the period from mid-80s to mid-90s.

This study has shown trends in young adult mortality in three large European cities and especially in AIDS, drug overdose, motor vehicle traffic accidents and suicide. AIDS increased in the three cities, changing the pattern of the main causes of death in Barcelona and Bologna. Munich presented a stable pattern, suicide being the main cause of death. It is worth mentioning that these causes of death are all avoidable causes, which should be a priority target for public health action at the local level.

As large urban areas are an appropriate setting to detect sentinel health events, we believe that greater efforts should be devoted at the European level to monitor trends in health outcomes and determinants in major cities, favouring more systematic and harmonised procedures to analyse and disseminate comparable results. Such efforts would contribute to improve the quality of public health policies and programme evaluations at local level.

The authors thank the following persons who participated in the project: Chiara Mancini (Project Manager), Manuel Tristan and Proje Arribas (IMSP), Kim Cabrero and Eva Martín (Barcelona Pere Arribas (IMSP), Kim Cabrero and Eva Martín (Barcelona Tecnologia), or who con
Teresa Brugal (IMSP).

Funding: this study was included in the PH-Net Project financed by the European Union (TEN-ISDN contract number 45 491)

Conflicts of interests: none.

1 Alonso I, Regidor E, Rodriguez C, et al. Principales causas de muerte en España, 1992. Med Clin (Barc) 1996;107:441-5

2 Ruiz-Ramos M, Blanes-Lloréns A, Viciana-Fernández F. La mortalidad en jóvenes y su impacto sobre la evolución de la esperanza de vida en Andalucía durante el periodo esperanza de vida en Andalucía durante el

3 Conti S, Masocco M, Farchi G, et al. Premature mortality in Italy during the first decade of the AIDS epidemic: 1984Italy during the first decade of the A

4 Montellà N, Borrell C, Brugal MT, et al. Evolución de la mortalidad en los jóvenes de la ciudad de Barcelona:19831993. Med Clin (Barc) 1997;108:241-7

5 Chenet L, McKee M, Otero A, et al. What happened to life expectancy in Spain in the 1980s? F Epidemiol Community Health 1997;51:510-14

6 Sarasqueta C, Zunzunegui V. Principales causas de mortalidad en jóvenes en la Comunidad Autónoma de Madrid: 1990-1991. Gac Sanit 1994;8:117-21.

7 Singh GK, Yu SM. Trends and differentials in adolescent and young adult mortality in the United States, 1950 through 1993. Am f Public Health 1996;86:560-4.

8 Castilla J, Martinez-Aragón MV, Gutierrez A, et al. Impact of human immunodeficiency virus infection on mortality among young men and women in Spain. Int $f$ Epidemiol 1997; 26:1346-51.

9 Goedert JJ, Pizza G, Gritti FM, et al. Mortality among drug users in the AIDS era. Int F Epidemiol 1995;24:1204-10.
10 Murray CJL, Lopez AD. Alternative projections of mortality and disability by cause 1990-2020: Global Burden of Disease Study. Lancet 1997;349:1498-504.

11 Valero LF, Sáenz MC. Mortalidad por infección VIH/sida en la comunidad de Castilla y León. Aten Primaria 1998;21:155-8.

12 AIDS reporting: update at 30 june 1999. CESES: HIV/AIDS Surveillance in Europe. http://www.ceses.org/ AidsSurv/aidsreporting.htm

13 La Vecchia C, Lucchini F, Levi F. Worldwide trends in suicide mortality, 1955-1989. Acta Psychiatr Scand 1994;90: 53-64.

14 Krug EG, Powell KE, Dahlberg LL. Firearm related death in the United States and 35 other high- and upper-middleincome coutries. Int f Epidemiol 1998;27:214-21.

15 Pritchard C. New patterns of suicide by age and gender in the United Kingdom and Western World 1974-1992; an indicator of social change? Soc Psychiatry Psychiatr Epidemiol 1996;31:227-34.

16 Diekstra RFW, Gulbinat W. The epidemiology of suicidal behaviour: a review of three continents. World Health Stat $Q$ 1993;46:52-68.

17 Heath KV, Frank O, Montaner JSG, et al. Human immunodeficiency virus (HIV)/acquired immunodeficiency syndrome (AIDS) mortality in industrialized nations, 19871991. Int F Epidemiol 1998;27:685-90.

18 Law MR, Morris JK. Why is mortality higher in poorer areas and in more northern areas of England and Wales? $\mathcal{F}$ Epidemiol Community Health 1998;52:344-52.

19 Mansfield CJ, Wilson JL, Kobrinski EJ, et al. Premature mortality in the United States: the role of geographic area, socioeconomic status, household type and availability of medical care. Am f Public Health 1999;89:893-8.

20 Shyrok HS, Siegel JS. The methods and materials of demography. New York: Academic Press, 1976.

21 OPS/OMS. Clasificación Internacional de Enfermedades, 9th revisión. Washington: 1975.

22 Can Laar M, Cruts G, Hartnoll R, et al. Coordination of the implementation of the EMCDDA standard guidelines on the drug-related deaths in the EU Member States, and the collection and analysis of information on drug-related deaths. Lisboa: European Monitoring Centre for Drugs and Drug European Monit

23 World Health Organization. World Health Statistics Annual, 1995. Geneva: WHO, 1996.

24 Rodriguez-Arenas MA, Zunzunegui MV, Friedman SR, et al. Sharing syringes in Madrid. Eur F Public Health 1996;6: 11-14.

25 European Centre for Epidemiological Monitoring of AIDS. HIV/AIDS surveillance in Europe. Quarterly report no 53, December 1997.

26 Blanch C, Vall M, Mompart A, et al. Impacto del sida en la mortalidad global de Cataluña,1981-1993. Med Clin (Barc) 1995;105:528-31.

27 European Monitoring Centre for Drugs and Drug Addiction. Extended annual report on the state of the drugs problem in the European Union. Lisboa: 1999.

28 Mezzelani P, Quaglio GL, Venturini L, et al. A multicentre study on causes of death among Italian injecting drug users. AIDS has overtaken overdose as the principal cause of death. AIDS Care 1998;10:61-7.

29 De la Fuente L, Barrio G, Vicente J, et al. The impact of drug related death on mortality among young adults in Madrid. Am f Public Health 1995;85:102-5.

30 Perucci CA, Davoli M, Rapiti E, et al. Mortality of intravenous drug users in Rome: a cohort study. Am $\mathcal{F}$ Public Health 1991;81:1307-10.

31 Frischer $\mathrm{M}$, Bloor $\mathrm{M}$, Goldberg D, et al. Mortality among injecting drug users: a critical reappraisal. $\mathcal{F}$ Epidemiol Community Health 1993;47:59-63.

32 Skidmore CA, Robertson JR, Savage G. Mortality and increasing drug use in Edinburgh:implications for HIV epidemic. Scott Med f 1990;35:100-2.

33 Morrisom A, Stone DH, Eurosic Working Group. Injury mortality in the European Union. Eur F Public Health 2000; 10:201-7.

34 Burvill PW, Armstrong BK, Carlson DJ. Atempted suicide and immigration in Perth, Western Australia, 1969-1978. Acta Psychiatr Scand 1983;68:89-99.

35 Platt S, Micciolo R, Tansella M. Suicide and unemployment in Italy: description, analysis and interpretation of recent trends. Soc Sci Med 1992;34:1191-201.

36 Neelman J. Regional suicide rates in the Netherlands: does religion still play a role? Int $\mathcal{F}$ Epidemiol 1998;27:466-72.

37 Crombie IK. Can changes in the unemployment rates explain the recent changes in suicide rates in developed countries? Int $\mathcal{F}$ Epidemiol 1990;19:412-16.

38 Lewis G, Slogget A. Suicide, deprivation, and unemployment: record linkage study. BMF 1998;317: 1283-6.

39 Preti A, Miotto P. Suicide and unemployment in Italy, 1982-1994. f Epidemiol Community Health 1999;53:694701.

40 Montgomery SM, Cook DG, Bartley MJ, et al. Unemployment pre-dates symptoms of depresion and anxiety resulting in medical consultation in yooung men. Int $\mathcal{f}$ Epidemiol 1999; 28:95-100.

41 Neeleman J, Lewis G. Suicide, religion, and socioeconomic conditions. An ecological study in 26 countries, 1990. $\mathcal{F}$ Epidemiol Community Health 1999;53:204-10.

42 Laumon B. Recherche épidemiologique et accidentologie routière en Europe. Rev Epidemiol Sante Publique 1998;46: $509-21$. 
43 Statistical report road accidents 1993-94. Paris: European

Conference of Ministers of Transport, 1998. SARTRE. European drivers and
des Ponts et Chausseés, 1994.

45 Brugal MT, Barrio G, Regidor E, et al. Discrepancias en el número de muertes por reacción aguda a sustancias psicoactivas registradas en España. Gac Sanit 1999;13:82-

6 Hessol NA, Buchbinder SP, Colbert D, et al. Impact of HIV infection on mortality and accuracy of AIDS reporting on death certificates. Am f Public Health 1992; 82:561-4.
47 Montellà N, Ricart I, Borrell C, et al. Comparación de las defunciones del registro de casos de sida y de las defunciones por sida del registro de mortalidad. Barcelona 48 Speechley M, Stavraky KM. The adequacy of suicide statisSpeechley M, Stavraky KM. The adequacy of suicide statis-
tics for use in epidemiology and public health. Can $\mathcal{F}$ Public

49 Jougla E, Pavillon G, Rossollin F et al. Improvement of the quality and comparability of causes-of-death statistics inside the European Community. Rev Epidem et Sante Publ $1998 ; 46: 447-56$.

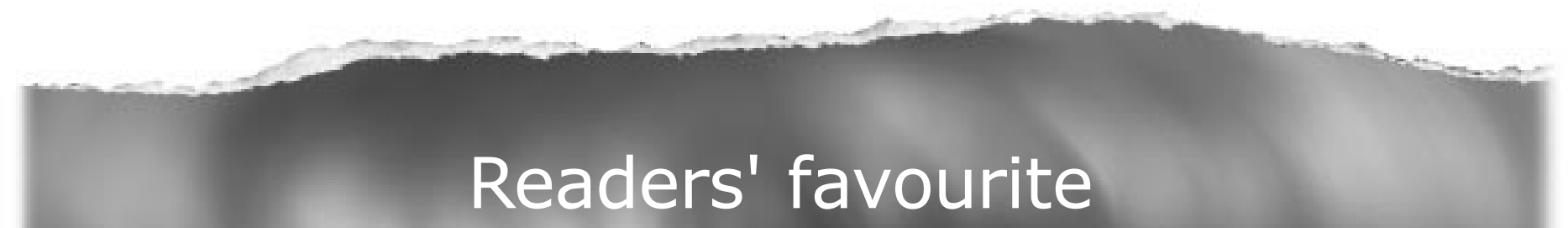

Top 10

Click on the "Top 10" button on the homepage to see which are the best read articles each month

\section{www.jech.com}

